\title{
Single and Multigland Disease in Primary Hyperparathyroidism: Clinical Follow-Up, Histopathology, and Flow Cytometric DNA Analysis
}

\author{
H. Jaap Bonjer, M.D., Hajo A. Bruining, M.D., Ph.D., Jan C. Birkenhager, M.D., Ph.D., \\ Ronald H. Nishiyama, M.D., Michael A. Jones, M.D., and C. Bruce Bagwell, M.D., Ph.D. \\ Departments of Surgery and Internal Medicine, University Hospital Dijkzigt, Rotterdam, The Netherlands and Department of Pathology, \\ Maine Medical Center and Maine Cytometry Research Institute, Portland, Maine, U.S.A.
}

\begin{abstract}
Two-hundred seventy-four patients with primary hyperparathyroidism had selective removal of enlarged parathyroid glands. Biopsies were taken from all parathyroid glands. Normal-size glands were not resected irrespective of their histological appearance. After a mean follow-up of 13.5 years the rates of persistent and recurrent hyperparathyroidism were, respectively, $3.6 \%$ and $0.7 \%$. Transient and permanent hypoparathyroidism occurred in $24 \%$ and $2.5 \%$ of the patients. The microscopic appearance of enlarged glands and of biopsies taken from normal-size glands were reviewed by two pathologists. Normal parathyroid glands were distinguished from abnormal glands fairly accurately (sensitivity $93 \%$, specificity $80 \%$ ). Microscopic classification of abnormal parathyroid glands as adenomas or hyperplastic glands correlated poorly with the gross classification as single or multigland disease. Flow cytometric DNA analysis of paraffin embedded parathyroid tissue showed significant differences for DNA index, \% S-phase and \% G2M $(p<0.001)$. Differentiating single from multigland disease by means of DNA analysis Was not possible. In conclusion, removal of only enlarged parathyroid glands results in acceptable rates of persistent and recurrent hyperparathyroidism. Biopsies should only be taken sparingly to prevent transient and permanent hypoparathyroidism. Microscopic examination and flow cytometric DNA analysis can differentiate normal from abnormal parathyroid glands but are unable to differentiate abnormal glands into single or multigland disease.
\end{abstract}

The surgical treatment and the pathology of primary hyperparathyroidism remain controversial subjects. Bilateral and unilateral surgical approaches have been advocated. Some surgeons use the histological appearance of parathyroid tissue at frozen section to determine the extent of parathyroidectomy [1-3]. When a hyperplastic parathyroid gland is reported by the pathologist, 3 or $3 \frac{1 / 2}{2}$ parathyroids are removed. In spite of this, histological criteria that reliably differentiate between adenoma and hyperplasia have not been firmly established [4, 5]. An alternative approach to parathyroid surgery is to rely solely on the gross characteristics of parathyroid glands. Only enlarged parathyroids are removed irrespective of their histological -

\footnotetext{
Presented at the International Association of Endocrine Surgeons in Stockholm, Sweden, August, 1991.

Reprint requests: H. Jaap Bonjer, M.D., Department of Surgery, St. Clara Hospital, Olympiaweg 350, 3078 HT Rotterdam, The Nether-
}

features. Opponents of this procedure argue that normal-size parathyroid glands with hyperplastic features are potentially hyperactive and should be removed to prevent persistent or recurrent hyperparathyroidism $[8,9]$.

In addition to histological and gross characteristics of parathyroid glands some authors have addressed the issue using DNA analysis as determined by flow cytometry to differentiate normal from hyperactive or potentially hyperactive parathyroid glands, and to establish if consistent differences are present in the DNA content of adenomas and hyperplastic parathyroid glands [10-13].

Our approach to parathyroidectomy is a bilateral one. Only enlarged parathyroids glands, estimated to weigh $>40 \mathrm{mg}$, are removed, irrespective of their histological pictures. In case of enlargement of 4 parathyroid glands, a remnant of parathyroid tissue equivalent to that of a normal parathyroid gland is left behind.

The objectives of this study were to determine if normal-size parathyroid glands are potentially hyperactive and to assess the ability of histopathology and DNA analysis to discriminate single from multigland disease.

\section{Methods}

\section{Patient Selection}

Six-hundred ninety-three patients had their initial parathyroid operations for primary hyperparathyroidism at either the University Hospital in Rotterdam or Leiden. Five-hundred fourteen patients had a single enlarged parathyroid gland and 179 patients had multiple enlarged parathyroid glands. From the 514 patients with single gland disease a representative sample of 160 patients was selected for follow-up. An attempt was made to follow all patients with multigland disease.

The initial diagnostic evaluation, details of surgical procedures, pathological features of the resected and biopsied parathyroid glands, and postoperative courses were reviewed. Patients with the syndromes of multiple endocrine neoplasia 1 and 2 (MEN 1 and 2) or familial hyperparathyroidism were ex- 
cluded, since in patients with these hereditary disorders the incidence of multigland disease and recurrent hyperparathyroidism are significantly higher than in non-familial hyperparathyroidism [14].

Two surgeons operated on the majority of the patients. The surgical approach is to first identify all parathyroid glands. The glands are carefully dissected free to evaluate abnormalities in their size and shape. Normal parathyroid glands are flat, while a globular shape is considered abnormal. Experience is required to properly estimate the weight of a parathyroid gland. From previous experience, we have adopted $40 \mathrm{mg}$ as the normal weight of a parathyroid gland. All glands estimated as weighing $>40$ milligrams are subsequently removed, and small biopsies are taken of all other identified glands. All biopsies are examined by frozen section. The identification of parathyroid tissue is the only information required from the pathologist. Further interpretation of the frozen sections varied but did not determine the extent of surgical resection of parathyroid tissue. When four parathyroid glands are enlarged, a $40 \mathrm{mg}$ remnant of parathyroid tissue is left in-situ. The weights of the removed parathyroid glands are recorded. A single enlarged gland is defined as one enlarged parathyroid gland weighing $>40 \mathrm{mg}$ with the other glands appearing normal in size. Multigland disease is defined as two or more enlarged parathyroid glands each estimated as weighing $>40 \mathrm{mg}$.

Follow-up of patients was carried out with the aid of the National Population Register, which registers all inhabitants of the Netherlands. Follow-up studies were performed either at the surgical clinics of the University Hospital Rotterdam or by family physicians. The follow-up studies consisted of a recording of medications, with emphasis on calcium or vitamin D supplementation. Two blood assays were drawn at weekly intervals. Serum levels of calcium, albumin, creatinine, and urea were determined. A serum parathyroid hormone (PTH) assay (IRMA 1-84 for the intact hormone, INCSTAR, Stillwater, Minnesota, U.S.A.) was performed when the mean calcium value, corrected for the serum albumin, exceeded $2.45 \mathrm{mmol} / \mathrm{L}$ (normal 2.20-2.65 mmol/L) to detect normocalcemic hyperparathyroidism.

Persistent hyperparathyroidism was defined as postoperative hypercalcemia caused by an enlarged parathyroid gland which was not found during the first attempt at parathyroidectomy. Recurrent hyperparathyroidism was defined as hypercalcemia due to an enlarged gland which was observed to be of normal size during the first operation. Duration of periods of normocalcemia were not part of these definitions.

\section{Histopathology}

The microscopic slides of biopsies and intact parathyroid glands removed from 236 patients who had follow-up studies were reviewed by two pathologists without knowledge of the operative findings, weights of the parathyroid glands, gross findings, or follow-up information. The review was limited to sections stained with hematoxylin and eosin. The presence or absence of the following features were recorded: lobularity, microscopic cellularity, cell types, stromal fat, a normal rim, transition from normal to abnormal tissue, a capsule, thick walled vessels, nuclear pleomorphism, mitotic activity, and blood/lymphatic vascular space involvement. Each gland was categorized as adenoma or hyperplasia based on the criteria of GhandurMnaymneh and Kimura [15], i.e., a mass is considered as an adenoma if it fulfilled the following criteria: absence of fat cells, absence of lobularity, a normal rim, and microscopic cellularity. A gland is considered hyperplastic if any one of the following criteria are met: fat cells in the mass, lobular architecture, or a transition of the abnormal tissue in the mass to normal parathyroid tissue. After independent review by pathologists, a consensus was reached on each case when there were disagreements. If no consensus could be reached, often due to inadequate samples of tissue, the case was considered unclassifiable.

A multidiscriminate analysis was done to assess the value of histological features in differentiating between normal parathyroid tissue, single and multigland disease.

\section{Flow Cytometric DNA Analysis}

Paraffin embedded material was available for DNA analysis from 66 patients. The enlarged parathyroid glands and the biopsies of parathyroid glands of normal sizes were fixed in $10 \%$ $(\mathrm{v} / \mathrm{v})$ neutral buffered formalin (NBF), processed routinely, and embedded in paraffin. Three to four $50 \mu \mathrm{m}$ sections of the paraffin blocks were deparaffinized in Americlear (Stephens Scientific Division, Oak Ridge, New Jersey, U.S.A.), rehydrated by sequential washes in graded ethanol $(100 \%, 95 \%, 70 \%$ and $50 \%(\mathrm{v} / \mathrm{v}))$, then washed in distilled water and allowed to equilibrate for 1 to 24 hours at room temperature. The tissue sections were dissociated in a $1 \%(\mathrm{w} / \mathrm{v})$ pepsin solution $(110$ units/mg protein, Sigma Chemicals, St. Louis, Missouri, U.S.A.) at $37^{\circ} \mathrm{C}$ for $30 \mathrm{~min}$, vortexing every $5 \mathrm{~min}$. The digested tissue suspensions were centrifuged at $1000 \times \mathrm{g}$ for $5 \mathrm{~min}$, and the cell pellets resuspended in 1-3 ml Earles Balance Salt Solution (Sigma Chemicals). Cell suspensions were filtered through $150 \mu \mathrm{m}$ stainless steel mesh (Small Parts, Inc. Miami, Florida, U.S.A.), recentrifuged, suspended in $1 \mathrm{ml}$ of low salt propidium iodide staining solution, incubated for $20 \mathrm{~min}$ at $37^{\circ} \mathrm{C}$, then $1 \mathrm{ml}$ of high salt propidium iodide staining solution was added. Each specimen was filtered through a $60 \mu \mathrm{m}$ nylon mesh (Small Parts, Inc.) into a new polystyrene tube, then analyzed on an Epics-C flow cytometer (Coulter Corporation, Hialeah, Florida, U.S.A.) at $400 \mathrm{~mW}$ of laser power with a $2 \mathrm{~W}$ argon ion laser.

All histograms were analyzed using Verity Modfit (Verity Software House, Inc., Topsham, Maine, U.S.A.), a cell cycle analysis program. The following parameters were calculated and analyzed: DNA index, $\%$ S-phase, $\%$ G2M, \% G2M minus doublets, debris, and total events. DNA index was defined as the ratio of the mean of the G0/G1 peak of the normal population. Populations with a DNA index between 0.9 and 1.1 were considered as DNA diploid populations. Cell populations were interpreted as DNA aneuploid when the DNA index was greater than 1.1 or smaller than 0.9. A DNA tetraploid population was defined as an DNA aneuploid population of cells at 4C DNA, including at least $20 \%$ of the total number of cells and another peak of cells at $8 \mathrm{C} \mathrm{DNA.} \mathrm{Doublets} \mathrm{were} \mathrm{calculated} \mathrm{by} \mathrm{interpo-}$ lating the heights of the singlet and triplet peaks. The $\% \mathrm{G} 2 \mathrm{M}$ minus the doublets was felt to represent a more accurate assessment of $\% \mathrm{G} 2 \mathrm{M}$ or $\% 4 \mathrm{C}$ cells. All results were analyzed using Excel (Microsoft Corporation, Redmond, Washington, 
Table 1. Serum calcium values at follow-up studies.

\begin{tabular}{lll}
\hline $\begin{array}{l}\text { Calcium } \\
(\mathrm{mmol} / \mathrm{L})^{a}\end{array}$ & $\begin{array}{l}\text { Single gland } \\
\text { disease }(\mathrm{n})\end{array}$ & $\begin{array}{l}\text { Multigland } \\
\text { disease }(\mathrm{n})\end{array}$ \\
\hline $2.20-2.45$ & 143 & 89 \\
$2.45-2.65$ & 14 & 15 \\
$>2.65$ & 3 & 10 \\
\hline
\end{tabular}

" Normal calcium $2.20-2.65 \mathrm{mmol} / \mathrm{L}$.

$\mathrm{n}$ : Number of patients.

U.S.A.). For comparison between the incidence of DNA diploid and DNA aneuploid populations among normal size, single and multiple enlarged parathyroid glands, a chi-square test was used. A Student t-test was used to compare means of $\%$ S-phase, \% G2M and the corrected \% G2M for doublets.

\section{Results}

\section{Clinical Follow-Up}

One-hundred and sixty patients with a single enlarged parathyroid gland were followed for a mean period of 12.8 years (range $4-35 \mathrm{yrs})$. The average age at the time of parathyroidectomy was 47.9 years (range, $12-73 \mathrm{yrs}$ ). Two thirds of the patients were females. The mean weight of the removed enlarged parathyroid glands was $1,556 \mathrm{mg}$ (range $115-16,767 \mathrm{mg}$ ).

Temporary hypocalcemia $(<2.20 \mathrm{mmol} / \mathrm{L})$ occurred in 43 $(22 \%)$ patients. Supplementation of calcium was withdrawn in 17 patients before discharge from the hospital. Only $2(1.2 \%)$ patients had permanent hypoparathyroidism after parathyroidectomy.

The levels of serum calcium at the time of follow-up studies are listed in Table 1. Parathyroid hormone assays were done in 9 patients with levels of serum calcium between 2.45 and 2.65 $\mathrm{mmol} / \mathrm{L}$. All were normal.

Three $(1.9 \%)$ patients with single gland disease had persistent hyperparathyroidism. At re-operation an enlarged parathyroid was found dorsal to the trachea in one patient, in the other, it Was located dorsal to the esophagus. The third patient had mild hypercalcemia, serum calcium of $2.70 \mathrm{mmol} / \mathrm{L}$, without symptoms and was not considered for re-operation. Recurrent hyperparathyroidism was not observed in patients with a single enlarged parathyroid gland.

Follow-up information was available on 114 of 179 patients with multigland disease. Forty-seven patients had died and the residence of 18 was unknown. The mean follow-up was 14.1 years (range 1-29 yrs). The average age at the time operation was 48.7 years (range 15-76 yrs). Distribution of females to males was $2: 1$. Only $18(9.8 \%)$ of 179 patients with multigland disease had four enlarged parathyroid glands. Forty $(22.1 \%)$ patients had three enlarged parathyroid glands, and $120(67 \%)$ patients had two enlarged glands. In one patient five enlarged glands were found. In the group of patients with two enlarged parathyroid glands, 72 patients had one parathyroid tumor on the right side and the other on the left. The mean weight of the enlarged parathyroids was $949 \mathrm{mg}$ (range 45-18,000 $\mathrm{mg}$ ).

Temporary hypocalcemia required calcium supplementation in $29(25.4 \%)$ patients. Nineteen patients had to continue Calcium medications after discharge from the hospital. Perma-
Table 2. Histological classification of parathyroid glands.

\begin{tabular}{llll}
\hline Classification & $\begin{array}{l}\text { Normal-size } \\
\text { glands }\end{array}$ & $\begin{array}{l}\text { Single enlarged } \\
\text { glands }\end{array}$ & $\begin{array}{l}\text { Multiple } \\
\text { enlarged } \\
\text { glands }\end{array}$ \\
\hline Normal & 316 & 6 & 70 \\
Adenoma & 2 & 58 & 22 \\
Hyperplasia & 10 & 48 & 84 \\
Unclassifiable & 11 & 18 & 30 \\
\hline
\end{tabular}

nent hypoparathyroidism occurred in $5(4.4 \%)$ patients. In 4 patients permanent hypoparathyroidism followed second operations for persistent hyperparathyroidism.

The serum calcium values at follow-up are shown in Table 1. Parathyroid hormone assays were done in 12 patients with serum levels of calcium between 2.45 and $2.65 \mathrm{mmol} / \mathrm{L}$. In 3 patients, elevated PTH values were found. Eight (7.0\%) patients had postoperative hypercalcemia due to persistent hyperparathyroidism. In 3 patients with persistent hyperparathyroidism, enlargement of 4 parathyroid glands was found at the first operation. Parathyroid glands weighing $160 \mathrm{mg}, 120 \mathrm{mg}$, and 100 $\mathrm{mg}$ were left behind. After removal of these glands at reoperation, permanent hypoparathyroidism followed in each case. Four patients had persistent hyperparathyroidism due to missed parathyroid tumors. The locations of these glands were dorsal to the trachea $(n=1)$, dorsal to the esophagus $(n=1)$, and within the thymus $(n=2)$. In one patient with persistent hyperparathyroidism the left lower parathyroid gland was considered to be normal in size at the first operation. At reoperation this gland was removed and weighed $250 \mathrm{mg}$. In all but one of the patients with persistent hyperparathyroidism the normocalcemic interval was $<6$ months. In one patient hypercalcemia developed 7 years after the first operation. Only 2 (1.8\%) patients had recurrent hyperparathyroidism. The normocalcemic intervals were 11 years and 19 years.

\section{Histopathology}

One-hundred and thirty patients with single gland disease and 91 patients with multigland disease had adequate clinical follow-up and pathologic material to be included in the histology study.

Of the 130 cases surgically classified as single gland disease, $58(44.6 \%)$ cases were histologically classified as adenomas, 48 $(36.9 \%)$ cases were classified as hyperplasia, $18(13.8 \%)$ cases were unclassifiable, and $6(4.7 \%)$ cases were classified as normal glands (Table 2). Two patients with a single enlarged parathyroid gland had persistent hyperparathyroidism. One patient had a single enlarged parathyroid gland removed which was interpreted as hyperplasia. The other patient had one enlarged gland removed and a biopsy of one normal-size gland. Both were interpreted as hyperplasia.

Two-hundred and six enlarged parathyroid glands were examined in the 91 patients classified by the surgeons as having multigland disease. Eighty-four (40.9\%) glands were histologically classified as hyperplasia, $70(33.9 \%)$ glands were classified as normal glands, $30(14.6 \%)$ glands were unclassifiable, and 22 $(\mathbf{1 0 . 6 \% )}$ glands were classified as adenomas (Table 2 ).

Six patients with multigland-disease had persistent hyper- 
Table 3. DNA pattern in parathyroid glands.

\begin{tabular}{llll}
\hline $\begin{array}{l}\text { DNA } \\
\text { pattern }\end{array}$ & $\begin{array}{l}\text { Normal-size } \\
\text { glands }\end{array}$ & $\begin{array}{l}\text { Single enlarged } \\
\text { glands }\end{array}$ & $\begin{array}{l}\text { Multiple enlarged } \\
\text { glands }\end{array}$ \\
\hline Diploid & 91 & 27 & 48 \\
Aneuploid & 0 & 8 & 10 \\
Tetraploid & 1 & 1 & 1 \\
\% S-phase & 1.89 & 3.64 & 3.48 \\
\% G2M & 6.94 & 8.03 & 9.96 \\
\hline
\end{tabular}

parathyroidism. In 3 of these patients all parathyroid glands were classified as normal glands, in the other 3 patients the glands were classified as hyperplasia. Recurrent hyperparathyroidism was observed in 2 patients. In 1 patient three enlarged parathyroid glands (all classified as hyperplasia) were removed at the first operation. Material from the normal-size parathyroid which was not resected was not available for study. After 19 years, hypercalcemia developed. A hyperplastic parathyroid gland was then found at autopsy. The other patient with recurrent hyperparathyroidism had two enlarged upper parathyroid glands which were removed at the first operation. Microscopic slides obtained at this operation were not available. Hypercalcemia developed after 11 years. At re-operation an enlarged left lower parathyroid gland was found and removed. This gland was classified as hyperplasia.

Biopsies of normal-size parathyroid glands taken from patients with single and multigland disease were combined and analyzed as a separate group. There were 339 glands in this group. Three-hundred and sixteen (93.2\%) glands were classified as histologically normal, $2(0.6 \%)$ glands were classified as adenomas, $10(2.9 \%)$ glands were classified as hyperplasia, and $11(3.2 \%)$ glands were unclassifiable (Table 2 ).

Multidiscriminate analysis revealed that the presence or absence of a normal rim, a capsule, chief or oxyphil cells, and nuclear pleomorphism did not contribute to differentiating among normal-size, single enlarged, and multiple enlarged parathyroid glands. The standardized canonical coefficients of these features were all below 0.15 [16]. Mitotic activity and blood/lymphatic vascular space involvement were not seen in any case. Comparing normal-size parathyroid glands and the combined group of single and multiple enlarged parathyroid glands showed a highly significant difference (Eigenvalue $=$ 1.0992). Microscopic cellularity was the most important differentiating feature. Comparing single enlarged and multiple enlarged parathyroid glands showed a far less significant difference (Eigenvalue $=0.317$ ). Microscopic cellularity, lack of stromal fat, presence of transition, and thick walled vessels indicated single gland disease, whereas clear cells and lobularity suggested multigland disease.

\section{Flow Cytometric Nuclear DNA Analysis}

Paraffin embedded material was available for flow cytometric nuclear DNA analysis from 39 patients with single gland disease and 27 patients with multigland disease. Ninety-two normalsize parathyroid glands were subjected to DNA analysis. Seventy-two glands were from patients with single gland disease and 20 glands were from patients with multigland disease. Ninety-one of 92 specimens showed cell populations with DNA diploid contents (Table 3). In one case a DNA tetraploid population (DNA index $=2.05$ ) was found. This was a biopsy of a normal-size gland from a patient who had two enlarged glands removed and who later developed an elevated PTH level and a serum calcium value of $2.68 \mathrm{mmol} / \mathrm{L}$.

DNA analysis of 36 enlarged parathyroid glands in patients with single gland disease showed DNA diploid populations in 27 glands (Table 3). Nine glands showed DNA aneuploid populations. Six glands were hyperdiploid and 2 glands showed both hypodiploid and hyperdiploid populations. A DNA tetraploid population was identified in 1 aneuploid gland. None of the patients with single gland disease had persistent or recurrent hyperparathyroidism.

Fifty-nine enlarged parathyroid glands obtained from 27 patients with multigland disease were available for DNA analysis. DNA analysis revealed cell populations with DNA diploid contents in 48 of 59 enlarged glands (Table 3). Eleven glands contained DNA aneuploid populations, 6 of which were hyperdiploid and 4 were hypodiploid. One aneuploid gland had a DNA tetraploid population. One patient had persistent hyperparathyroidism due to a left lower enlarged parathyroid which was missed at the first operation. After removal of this gland normocalcemia followed. DNA analysis of the left lower gland showed a DNA diploid pattern with $9.2 \%$ of cells at $4 \mathrm{C}$.

The mean weight of single enlarged parathyroid glands with DNA diploid populations was 2,092 $\mathrm{mg}$ (range $115-16,676 \mathrm{mg}$ ) while the mean weight of single enlarged glands with DNA aneuploid populations was $3,229 \mathrm{mg}$ (range $310-12000 \mathrm{mg}$ ). A Student t-test revealed no significant difference $(t=0.78)$.

In multiple gland disease the mean weight of enlarged glands with DNA diploid populations was $2,027 \mathrm{mg}$ (range 100-16,000 mg) while the mean weight of enlarged glands with DNA aneuploidy was $1,150 \mathrm{mg}$ (range $45-18,000 \mathrm{mg}$ ). Comparison of the mean weights showed no significant difference $(t=0.80)$.

A chi-square test was used to compare the incidence of DNA diploid and DNA aneuploid populations of cells in normal-size parathyroid glands, single enlarged glands, and multiple enlarged glands. The differences were statistically significant when comparing normal-size glands with enlarged glands in single gland disease $(p<0.001)$ or multiple gland disease $(p<$ 0.001 ). However, there was no statistically significant difference in the incidences of aneuploidy in single and multiple gland disease.

The Student t-test was used to compare the mean percentage of cells in the $S$ and G2M phases among the three groups. There was a statistically significant difference between the normal-size and enlarged glands $(p<0.001)$, but none between the single and multiple enlarged glands.

\section{Discussion}

The bilateral approach to the neck is most frequently used in parathyroid surgery [17-20]. An attempt is made to identify all parathyroid glands during the exploration of both sides of the neck. Proponents of the unilateral approach note that the bilateral approach is associated with significantly longer operative time and higher incidences of transient and permanent hypoparathyroidism and injury to the recurrent laryngeal nerve $[21,22]$. Tibblin and associates [21] recorded that the average length of unilateral procedures was 22 minutes shorter when 
compared to bilateral procedures. In a comparative study by Tibblin and coworkers [21] the occurrence of postoperative hypocalcemia was observed. After the second postoperative day the serum calcium returned to normal levels in the patients undergoing unilateral exploration while in the patients who had bilateral operations with biopsies from normal-size glands hypocalcemia persisted for several days. Approximately one-third of the patients with bilateral operations required temporary supplementation of calcium. At follow-up only 2 of 50 patients with bilateral operations needed vitamin $\mathbf{D}$ supplementation.

The occurrence of transient hypocalcemia after bilateral operations is most likely influenced by the biopsy of normalsize glands. In several studies, rates of transient hypocalcemia ranging from $22 \%$ to $48 \%$ have been reported when biopsies were taken from all parathyroid glands $[23,24]$. When biopsies were taken only sparingly, the rate of transient hypocalcemia was significantly lower. Transient hypocalcemia was recorded in our study in $22 \%$ of patients with single gland disease and in $25.4 \%$ of patients with multiple gland disease. To prevent transient and permanent hypoparathyroidism biopsies are now taken solely to ascertain the nature of the tissue when gross examination is not helpful.

The proponents of the unilateral approach adhere to the concept that primary hyperparathyroidism is caused by enlargement of a single parathyroid gland (adenoma) or by enlargement of all glands (hyperplasia). The unilateral approach is only applicable to single gland disease. When one enlarged and one normal gland are identified on the same side of the neck, single gland disease is believed to be present and the operation is terminated. To differentiate between normal and abnormal glands Tibblin and colleagues [25] rely on the amount of intracellular fat. Wang [22] uses the density test which measures the difference in total fat content of two parathyroid glands. Low content of intracellular or stromal fut would indicate hormonal hyperfunction. However, several studies have shown that the intracellular and stromal fat content vary widely in normal and abnormal parathyroid glands [26, 27].

In our opinion, primary hyperparathyroidism can be caused by enlargemient of only 2 or 3 parathyroid glands. In our study, 120 patients had 2 enlarged glands, and 40 patients had 3 enlarged glands. Seventy-two of the patients with 2 enlarged glands had I enlarged parathyroid on the right side of the neck and the other on the left. An unilateral approach in these patients could have resulted in a high incidence of persistent hyperparathyroidism. A study by Wells and coworkers [7] recorded 2 or 3 gland disease in $22 \%$ of all patients, which is in accordance with the incidence $(23 \%)$ in our study.

The extent of resection of parathyroid tissue in patients with multiple enlarged glands remains controversial. One group of authors advocates subtotal parathyroidectomy in patients with enlargement of two or more parathyroid glands or in the presence of histological features indicating hyperplasia [1-3, 9, 28]. However, the microscopic criteria for hyperplasia are poorly defined. In our histology study we were unable to delineate microscopic features which characterize hyperplasia. The motive to perform subtotal parathyroidectomy is the asSumption that normal-size parathyroid glands in multiple gland disease are potentially hyperactive and can cause persistent and recurrent hyperparathyroidism. Another group of authors does not consider normal-size glands as potentially hyperactive and, therefore, selectively removes enlarged glands irrespective of the microscopic findings $[6,7,29,30]$. This protocol would be associated with high incidences of persistent and recurrent hyperparathyroidism when normal-size glands are potentially hyperactive. However, the rate of persistent hyperparathyroidism after subtotal parathyroidectomy varies from $5 \%$ to $15 \%$, whereas the persistence rate after selective removal of enlarged glands varies from $1 \%$ to $4 \%$. In our study, which undertook selective removal, the persistence rate was $9.6 \%$. Recurrent hyperparathyroidism was reported in $0.4 \%$ to $16 \%$ of the patients after subtotal parathyroidectomy, while removing only the enlarged glands was associated with recurrence rates varying between $0.4 \%$ and $8 \%$. The recurrence rate in our study was $1.8 \%$.

In conclusion, evidence is lacking that normal-size parathyroid glands are potentially hyperactive. Removal of only the enlarged glands results in acceptable rates of persistent and recurrent hyperparathyroidism. To prevent transient and permanent hypoparathyroidism a conservative approach to the extent of resection of parathyroid tissue and to the taking of biopsies is preferable.

The aim of our histopathology study was to determine if microscopic examination of parathyroid tissue can differentiate among normal parathyroid glands, single enlarged glands, and multiple enlarged glands. Biopsies of normal-size parathyroid glands were histologically classified as "normal" in $93.2 \%$ of cases. The specificity of the histological diagnosis of "normal" was $80 \%$ because one-third of the multiple enlarged glands were called "normal" by the pathologists. Of the 130 cases classified as single gland disease, only $44.6 \%$ were histologically classified as "adenomas", A compressed rim of "normal" parathyroid tissue, which is the most traditional finding in parathyroid adenomas, was only present in one-third of the single enlarged glands. Recognizing the shortcomings of the traditional criteria and accepting the concept of "focal hyperplasia", GhandurMnaymneh and Kimura [15] reclassified 172 patients with primary hyperparathyroidism. Of 144 cases considered to be hyperplastic, 129 cases showed only single gland enlargement and thus, were considered as examples of "focal hyperplasia". Our results are similar to these of Ghandur-Mnaymeh and Kimura in that many, nearly $40 \%$, of our cases with single gland disease were classified histologically as examples of hyperplasia.

Our results show that the microscopic classification of abnormal parathyroid glands as hyperplasia or adenoma correlates poorly with the gross classification as single gland disease and multigland disease. However, the pathologist can distinguish normal from abnormal parathyroid glands with a fair degree of accuracy. We feel that this distinction should be the primary aim of microscopic examination of frozen and permanent sections.

The inability to discriminate microscopically between single gland disease and multigland disease has led to a quest for objective means to make this differentiation. Flow cytometric DNA analysis has been used for this purpose.

One of the issues to be resolved is if flow cytometric DNA analysis can detect potentially hyperactive parathyroid glands which are normal in size. In a study by Irvin and colleagues [11] the mean of the percentage of cells at $4 \mathrm{C}(\mathrm{G} 2 \mathrm{M})$ of normal-size glands was $7.48 \%$. Eleven patients had normal-size glands that 
had $\% 4 \mathrm{C}$ greater than $6 \%$. In 7 of these patients elevated serum PTH levels were found postoperatively. Levels of serum PTH were normal in all patients who had normal-size glands with $\%$ $4 \mathrm{C}$ less than $6 \%$. The mean $\% 4 \mathrm{C}$ of the normal-size glands in our study was $6.94 \%$. Two patients had persistent hyperparathyroidism. In 1 patient the enlarged parathyroid gland which was missed at the first operation showed a DNA diploid pattern with \% $4 \mathrm{C}$ of $9.2 \%$. In the other patient a DNA tetraploid population ( $\% 4 \mathrm{C}$ greater than $20 \%$ ) was found in a normal-size gland. One aneuploid gland was reported by Irvin and associates [11] and this normal-size gland was found in a patient who had elevated PTH levels postoperatively.

The value of the percentage of cells in the S-phase in predicting persistent hyperparathyroidism is difficult to assess because the $\% \mathrm{~S}$-phase is not reported in other studies. In our study a correlation between $\%$ S-phase and persistent hyperparathyroidism was not found.

The percentage of single enlarged glands (adenomas) with DNA aneuploidy are reported in several studies and vary from $5 \%$ to $26 \%[11,12,31,32]$. In our study $22 \%$ of the single enlarged glands had DNA aneuploid populations. Joensuu and Klemi [32] in their study of DNA aneuploidy in adenomas of endocrine organs state that DNA aneuploidy occurs commonly in several types of human endocrine adenomas. The prognosis of aneuploid adenomas appears to be as good as that of diploid ones, but little is known about their tendency to progress into histologically and clinically malignant neoplasms if left in place.

Multigland disease (hyperplasia) is defined differently in various studies. Bowlby and coworkers [12] defined primary hyperplasia by the gross identification of 3 enlarged glands, each weighing $>60 \mathrm{mg}$. In 2 of 10 glands DNA tetraploidy was reported. Irvin and associates [11], who required microscopic confirmation of hyperplasia, reported aneuploidy in 1 hyperplastic gland. Aneuploidy was observed in our material in 10 hyperplastic glands and tetraploidy in 1 hyperplastic gland.

Significant differences were found in the incidence of DNA aneuploidy and the mean percentage of cells in the S-phase or G2M phase when comparing normal-size and abnormal glands, but none between single gland disease and multigland disease. These results merely confirm the conclusions of our histopathologic study that normal glands can be identified with a fair degree of accuracy, but the distinction of single gland disease from multigland disease is essentially impossible.

In conclusion, removal of only enlarged parathyroid glands in primary hyperparathyroidism is associated with acceptable rates of persistent and recurrent hyperparathyroidism. In this long-term follow-up study, evidence is lacking that normal-size parathyroid glands are potentially hyperactive. The role of microscopic examination of parathyroid tissue seems to be limited to the distinction of normal from abnormal parathyroid tissue. Flow cytometric DNA analysis can objectively differentiate normal from abnormal parathyroid glands. The application of flow cytometric DNA analysis appears to be in its early stages. More studies remain to be done. Until these are completed, it appears premature to make any conclusive statements concerning the role that DNA analysis may play in the elucidation of the pathogenesis of primary hyperparathyroidism or the contributions it may make to the evaluation and care of patients with this disease.

\section{Résumé}

Deux cent soixante quatorze patients ayant une hyperparathyroïdie primaire ont eu une exérèse élective des glandes parathyroïdes hypertrophiques. Des biopsies ont été prélevées au niveau de toutes les glandes parathyroïdiennes. Les glandes de taille normale ont été laissées en place quel que soit leur aspect histologique. Après un suivi moyen de 13.5 ans, les taux d'hyperparathyroïdie persistante et de récidive étaient observés chez $3.6 \%$ et $2.5 \%$ des patients. Une hypoparathyroïdie transitoire est survenue dans $24 \%$ des cas et elle était permanente chez $2.5 \%$ des patients. Les lames provenant des glandes hypertrophiques et des biopsies réalisées au niveau des glandes de taille normale ont été revues par deux anatomopathologistes. On a pu distinguer les glandes parathyroïdes normales des glandes anormales avec une assez bonne précision (sensibilité 93\%, spécificité $80 \%$ ). La classification histologique des anomalies parathyroïdiennes en adénome et en hyperplasie était mal correlée à la classification selon le caractère unique ou multiple de l'atteinte glandulaire. Une analyse de l'ADN par cytométrie de flux sur les coupes de tissu parathyroïdien inclus dans la paraffine a montré des différences significatives en ce qui concerne l'index ADN, le pourcentage de phase $S$ et de G2M ( $p$ $<0.001$ ). Il n'était pas possible, d'après l'analyse de l'ADN, de faire la différence entre atteinte uni ou pluriglandulaire. En conclusion, l'éxérèse des seules glandes hypertrophiques donne des résultats acceptables en ce qui concerne le taux de persistance ou de récidive de l'hyperparathyroïdie. Des biopsies ne devraient être prélevées que dans des cas sélectionnés pour prévenir l'hypoparathyroïdie permanente ou transitoire. L'examen histologique et l'analyse par cytométrie de flux peuvent différencier les glandes normales des parathyroïdes pathologiques mais ne sont pas capables de distinguer atteintes uni et multiglandulaires.

\section{Resumen}

Doscientos setenta y cuatro pacientes con hiperparatiroidismo primario fueron sometidos a resección selectiva de las glándulas paratiroides aumentadas de tamaño. Se tomaron biopsias de la totalidad de las glándulas paratiroides; las paratiroides de tamaño normal fueron dejadas, sin tener en cuenta la apariencia microscópica. En un seguimiento promedio de 13.5 años las tasas de hiperparatiroidismo persistente o recurrente fueron $3.6 \%$ y $2.5 \%$, respectivamente. Se observó hipoparatiroidismo transitorio en $24 \%$ y permanente en $2.5 \%$ de los pacientes. Los cortes microscópicos de las glándulas aumentadas de tamaño y de las biopsias de las glándulas de tamaño normal fueron revisadas por dos patólogos. La diferencia entre glándulas normales y glándulas anormales fue establecida con bastante certeza $($ sensibilidad $=93 \%$, especificidad $=80 \%$ ). La clasificación microscópica de las glándulas anormales entre adenomas $e$ hiperplasia se correlacionó pobremente con la clasificación macroscópica entre enfermedad uniglandular o enfermedad multiglandular. El análisis de DNA por citometría de flujo del tejido paratiroideo incluido en parafina demostró diferencias significativas en cuanto al índice de DNA, el \% de formas $\mathrm{S}$ y el \% de G2M $(p<0.001)$. La diferenciación entre enfermedad uniglandular y enfermedad multiglandular no fue posible mediante el análisis de DNA. En conclusión, la resección de sólo las 
paratiroides aumentadas de tamaño resulta en tasas aceptables de hiperparatiroidismo persistente o recurrente. Sólo ocasionalmente se deben tomar biopsias, para así evitar el hipoparatiroidismo transitorio o permanente. El examen microscópico y el análisis de DNA por citometría de flujo pueden diferenciar entre glándulas paratiroides normales y glándulas anormales, pero no entre enfermedad uniglandular y enfermedad multiglandular.

\section{References}

1. Rudberg, C., Akerstrom, G., Palmer, M., Ljunghall, S., Adami, H. O., Johansson, H., Grimelius, L., Thoren, L., Berstrom, R.: Late results of operation for primary hyperparathyroidism. Surgery 99:643, 1986

2. McGarity, W.C., Mckeown, P.P., Sewell, C.W.: The role of routine biopsy of all parathyroid glands in primary hyperparathyroidism. Am. Surg. 5l:8, 1985

3. Cooke, T.J.C., Boey, J.H., Sweeney, C.W.: Parathyroidectomy: Extent of resection and late results. Br. J. Surg. 64:153, 1977

4. Black, W.C., Utley, J.R.: The differential diagnosis of parathyroid adenomas and chief cell hyperplasia. Am. J. Clin. Pathol. 49:761, 1967

5. Saxe, A.W., Baier, R., Tesluk, H., Toerson, W.: The role of the pathologist in the surgical treatment of hyperparathyroidism. Surg. Gynecol. Obstet, 161:101, 1985

6. Clark, O.H., Way, L.W., Hunt, T.K.: Recurrent hyperparathyroidism. Ann. Surg. 179:729, 1974

7. Wells, S.A., Leight, G.S., Hensley, M., Dilley, W.G.: Hyperparathyroidism associated with the enlargement of two or three parathyroid glands. Ann. Surg. 202:533, 1985

8. Paloyan, E., Paloyan, D., Pickleman, J.R.: Hyperparathyroidism today. Surg. Clin. North Am. 53:211, 1973

9. Haff, R.C., Amstrong, R.G.: Trends in the current management of primary hyperparathyroidism. Surgery 75:715, 1974

10. Irvin, G.L., Bagwell, C.B.: Identification of histologically undetectable parathyroid hyperplasia by flow cytometry. Am. J. Surg. $138: 567,1979$

11. Irvin, G.L., Taupier, M.A., Block, N.L., Reiss, E.: DNA patterns in parathyroid disease predict postoperative parathyroid hormone secretion. Surgery 104:115, 1988

12. Bowlby, L.S., DeBault, L.E., Abraham, S.R.: Flow cytometric DNA analysis and parathyroid surgery. Am. J. Pathol. 128:338, 1987

13. Rosen, I.B., Musclow, C.E.: DNA histograms of parathyroid tissue in determining extent of parathyroidectomy. Surgery 98:1024, 1985

14. Lamers, C.B.H.W., Froeling, P.G.A.M.: Clinical significance of hyperparathyroidism in familial multiple endocrine adenomatosis type I (MEA I). Am. J. Med. 66:422, 1979

\section{Invited Commentary}

\author{
Henry Johansson, M.D. \\ Department of Surgery, University Hospital. Uppsala, Sweden
}

The ideal surgical treatment of primary hyperparathyroidism has remained an almost unresolved issue and the present study has not contributed towards solving the problem. However, the authors have somewhat provocatively helped to keep the debate alive. In an interesting paper they have raised the question as to whether the surgical strategy in primary HPT
15. Ghandur-Mnaymneh, L., Kimura, N.: The parathyroid adenoma: A histologic definition with a study of 172 cases of primary hyperparathyroidism. Am. J. Pathol. 115:70, 1984

16. Van de Geer, J.P.: Introduction to Multivariate Analysis for the Social Sciences, W.H. Freeman and Company, San Francisco. 1982, pp. 201-254

17. Bruining, H.A., Van Houten, H., Juttmann, J.R., Lamberts, S.W.J., Birkenhager, J.C.: Results of operative treatment of 615 patients with primary hyperparathyroidism. World J. Surg. 5:85. 1981

18. Thompson, N.W.: The techniques of initial parathyroid exploration and reoperative parathyroidectomy. In Endocrine Surgery Update, N.W. Thompson, A.I. Vinik, editors, Grune and Stratton, New York, 1985, pp. 365-374

19. Edis. A.J.: Surgical anatomy and technique of neck exploration for primary hyperparathyroidism. Surg. Clin. North Am. 57:495, 1977

20. Rothmund, M.: Therapie des primären hyperparathyreodismus. In Hyperparathyreodismus, M. Rothmund, editor, Georg Thieme Verlag, Stuttgart-New York, 1980, pp. 160-165

21. Tibblin, S., Bondeson, A.G., Ljungberg, O.: Unilateral parathyroideciomy for solitary parathyroid adenoma. In Fortschritte der Endokrinologischen Chirurgie, M. Rothmund, F. Kummerle, editors, Georg Thieme Verlag, Stuttgart-New York, 1981, pp. 114-119

22. Wang. C.A.: Surgical management of primary hyperparathyroidism. Curr. Probl. Surg. 12:11, 1985

23. Edis, A.J., Beahrs, O.H., Van Heerden, J.A., Akwari, O.E.: "Conservative" versus "liberal" approach to parathyroid neck exploration. Surgery 92:827, 1977

24. Kaplan, E.L., Bartlett, S., Sugimoto, J., Fredland, A.: Relation of postoperative hypocalcemia to operative techniques: Deleterious effects of excessive use of parathyroid biopsy. Surgery 92:827, 1982

25. Bondeson, A.G., Bondeson, L., Ljungberg, O., Tibblin. S.: Fat staining in parathyroid disease: Diagnostic value and impact on surgical strategy: Clinicopathologic analysis of 191 cases. Hum. Pathol. 16:1255, 1985

26. Dufour, D.R., Wilkerson, S.Y.: The normal parathyroid revisited: Percentage of stromal fat. Hum. Pathol. 13:717, 1982

27. Dekker, A., Dunsford, H.A., Geyer, S.I.: The normal parathyroid gland at autopsy: The significance of stromal fat in adult patients. $J$. Pathol. 128:127, 1979

28. Paloyan, E., Lawrence, A.M., Baker, W.H., Straus, F.H.: Neartotal parathyroidectomy. Surg. Clin. North Am. 49:43, 1969

29. Myers, R.T.: Follow-up study of surgically treated primary hyperparathyroidism. Ann. Surg. 179:729, 1974

30. Harlow, S., Roth, S.1., Marshall, R.B.: Flow cytometric DNA analysis of normal and pathologic parathyroid glands. Mod. Pathol. $4: 310,1991$

31. Joensuu, H., Klemi, P.J.: DNA analysis in adenomas of endocrine organs. Am. J. Pathol. 132:145, 1988

should not be based solely on a gross examination of the parathyroid glands rather than on a proper histopathological diagnosis. The rationale of their recommendation is their view that the choice of surgical procedure should preferably rely upon an evaluation of the glandular size and is best made by an experienced surgeon at operation.

This view can, of course, be discussed. A major problem in parathyroid histopathology concerns the discrimination between adenoma and hyperplasia (chief cell type), but modern histochemical techniques may decisively contribute to the distinction between single gland and multigland disease.

In the present study there was a considerable discrepancy between the microscopic and macroscopic evaluation irrespec- 